The Geneva Papers on Risk and Insurance, 16 (No. 61, October 1991), 414-418

\title{
How the Uruguay Round Services Negotiations Will Affect Worldwide Insurers
}

\author{
by Oakley Johnson*
}

\section{Introduction}

These notes are intended to present my views on the importance of the Uruguay Round services trade negotiations for worldwide insurers such as American International Group. I also want to emphasize the perilous state in which those negotiations currently find themselves. A successful outcome to the GNS negotiations - in the form of a binding multilateral agreement among countries and with at least a modest package of initial liberalization commitments - is important not only to my company but, I believe, for many other insurance companies wherever they operate worldwide.

\section{Where insurance fits in to the Uruguay Round}

The Group of Negotiations on Services (GNS) is only one of fifteen different negotiating groups operating since 1986 when the Uruguay Round was begun. Its importance, however, is much greater than this would suggest. Along with agriculture, services is undoubtedly the most charged and critical area of the ongoing negotiations. The insurance industry has a long history of support for the concept of an overall multilateral framework for trade in services. In fact, our chairman at AIG, Maurice Greenberg, was one of the founder of the U.S. Coalition of Services Industries in the U.S. when it was established in 1980 to press for just such an objective.

Why is multilateral trade liberalization important for insurance? The insurance industry worldwide has grown up primarily as a set of national markets for life insurance, various forms of non-life insurance, and specialized insurance markets for large risks, transportation, etc. Only the reinsurance markets can be characterized as a relatively open market. The barriers to international trade in insurance services are legion and take different forms:

- total market denial through restrictive licensing or monopoly practice;

- discriminatory reserve requirements for financial services providers;

* Corporate Vice-President, American International Group. Conference presented at the Second Geneva International Forum on Global Services and Trade Liberalization on May 21, 1991. 
- profit repatriation restrictions;

- discriminatory local investment restrictions;

- compulsory reinsurance by state monopolies;

- prohibitions on foreign marine insurance by foreign companies.

These barriers to international trade in insurance services currently exist not only in the developing countries and in the former socialist countries but also are encountered among the Asian NIC's, the more progressive Latin American states, India, Japan, and the EC. I make no comment on the situation in the U.S. itself other than to note that hundreds of foreign insurers and reinsurers currently operate in the U.S. market, either on an admitted and non-admitted basis, and account for between $25-30 \%$ of total market share.

What the Uruguay Round services trade negotiations are primarily about is the clear identification and progressive reduction of such barriers to trade in services, both generally and in specific sectors like insurance. The GNS has laboured hard over the past four years and produced draft elements of a framework of principles and rules which, if agreed to and put into effect by governments, would govern trade in services in insurance and any other services sector not specifically exempted or reserved in whole or in part by signatories to an eventual agreement. Moreover, as one traditional pillar within the dynamic financial services field, the insurance/reinsurance/brokerage functions would also be prominently treated with a proposed sectoral annex on financial services. This financial services annex has been the subject of informal and formal discussions for almost two years and the prospects are good that a suitable text can be finalized among OECD countries within the next month or so and which can then be discussed with the ASEAN and other countries.

In addition to an overall framework and sectoral annex on financial services, a successful outcome to the Uruguay Round services trade negotiations will require negotiation of an initial set of liberalization commitments among parties to an eventual multilateral agreement. What this involves is the exchange by each country of concessions relating to market access and national treatment, i. e. the elimination of existing barriers to services trade. To this end, countries are currently submitting conditional offers of sectors or sub-sectors where they are prepared to bind current or future level of liberalization and will soon begin to make requests of other countries in terms of reducing or eliminating what they consider to be existing barriers to services trade. These negotiated concessions would then be set out in each country's schedule of liberalization commitments and become an integral part of the final agreement. But if there are no substantial liberalization commitments, ther should be no agreement.

\section{The U.S. insurance industry position}

The guiding principles underlying the U.S. insurance industry position on a Uruguay Round services trade agreement are simple and straightforward: the agreement must have commercial value; and we are opposed to any mere codification of the status quo. More specifically, the U.S. insurance industry wants an agreement that meets the following key objectives:

- Market Access abroad - particularly in markets now closed;

- binding commitments to liberalize, including opportunity to compete with monopolies or to eliminate them altogether;

- freedom to establish by any means - including by acquisition/merger - so as to be able to provide service on a national treatment basis; 
- highest possible standards of openness - including cross-border rights for reinsurance, marine/aviation insurance - with the bare minimum of reservations and derogations.

To this end, we as an industry would be willing to accept fewer country signatories in the first instance if this is required to meet these goals.

Multilateral trade liberalization is not the only way in which many of these goals can be accomplished. The U.S. holds a powerful unilateral instrument for opening foreign markets to fair competition through use (or threatened use) of the Section 301 provisions of its Trade Act. This has already shown its effectiveness, for example, with regard to the Korean insurance market. Other countries quite naturally seek to curb the use of such unilateral instruments. We in the U.S. insurance industry advocate no curb on future use of Section 301 as part of any multilateral services trade agreement unless certain conditions are met:

- other countries must make meaningful commitments to liberalize insurance and other sectors;

- they agree to subscribe to the GATT dispute settlement provisions or any modifications agreed to as part of the financial services annex;

- they accept the concept of cross-sector retaliation;

- there is no backsliding through the adoption of new restrictions.

Let me emphasize here three points. First, we believe that the U.S. position is generally shared by the insurance industries in other developed countries. In this regard, we would point to the broadly similar position adopted by the Comité Européen des Assurances. Second, we recognize that the U.S. government itself will need to make certain liberalization commitments, for example, individual state licensing/guarantee provisions or fund requirements for large commercial lines. Third, we would very much like to see an eventual multilateral services trade agreement covering all services sectors. However, if that proves impossible, we are not opposed to a "stand-alone" financial services agreement. We will support whatever gets the job done!

\section{How insurers would be affected by a multilateral agreement}

Achieving a Uruguay Round services trade agreement offers a historic opportunity. No international standard has ever governed the behaviour of governments in the services field so as to promote liberalization and expansion of trade across borders. In adopting a multilateral agreement, countries and the international community will be adopting an economic constitution for future decades.

How will its principles and rules affect insurers?

- First, it will codify existing principles and rules affecting cross-border provision of insurance services. This is particularly so with regard to "freedom of service" as Europeans tend to refer to it.

- Second, a multilateral services trade agreement will guarantee the right to establish a "commercial presence" in inarkets where this may at present be restricted or denied. This is at the very core of market access.

- Third, it will help to eliminate internal/local barriers to investment in foreign markets and access to foreign capital markets. This has been a sore point in the insurance industry with all the merger/acquisition activity which has been taking place. 
- Fourth, it will help to constrain future discriminatory actions on the part of governments vis-à-vis foreign insurance companies both in terms of attempted nationalization and the imposition of local content provisions. An agreement would provide dispute settlement mechanisms whereby rights of retaliation or compensation might be arrived at.

- Fifth, it would cstablish as an international goal for the eventual elimination of barriers to market access, discrimination among foreign and domestic providers of insurancc services, provide rights in international economic law to those who previously had little recoursc, and reduce the impact of state-run monopolics in the insurance field. This may sound a bit too optimistic but the potential is therc.

- Sixth, a multilateral scrvices tradc agrcement would crcatc new disciplines and standards to which not only initial but also futurc country signatorics will have to subscribc. This may eventually include futurc GATT members like China and the Soviet Union.

Thus the ovcrall, long-term importance of a multilatcral serviccs trade agrccment for the world insurance industry should not bc underestimated.

\section{The current perilous state of the GNS negotiations}

The current state of the GNS negotiations does not look good. ${ }^{1}$ In the wake of Brussels, we are all aware that a successful outcome to the overall negotiations - including the services trade negotiations - is still contingent on a deal on agriculture. With regard to services, there has been more progress but still more to accomplish, especially with regard to finalizing the framework and scheduling initial commitments.

I can report, however, that the substantive text of a financial services annex is almost finished and, from the insurance industry perspective at least, seems to be in good shape. We are particularly pleased to have exceptionally good language on the right of financial services operators to establish across borders. The key will be in the country schedules and what governments will be willing to bind in order to bring local practice into conformity with general principles.

With regard to scheduling of commitments, the U.S. has taken the lead since February of this year in conducting bilateral consultations in Geneva and national capitals with all 22 countries which have thus far submitted conditional offers. The U.S. is also the only country which has thus far advanced its list of liberalization requests to other countries involved in the GNS negotiations, a document which lists some 800 barriers to liberalized trade and many of which relate to insurance. Virtually every country finds a place on this U.S. request list.

Out of the 22 offers which countrics have submittcd to datc, many include insurance but almost all involve "standstill" rather than substantive liberalization. This is not sufficient by any mcans. Nevcrtheless, the bilateral discussions to date have been most useful, in understanding how different countrics would apply framcwork principles and rules and in providing clarification as to what individual offers really mean. What "commercial presence" would mean to various countrics and spccifically with rcgard to insurance is a casc in point. However, the consultations undertaken thus far do not constitute real negotiations wherc concessions are exchanged nor, in our judgment, have any market opening measures

I Situation in June 1991. 
yet been offered. The key question we in the U.S. insurance and other service sectors are asking is: When will the real negotiating process begin?

The effects of delay and the current stalled negotiations are already becoming apparent. In some cases such as Peru, Mexico and Venezuela, countries have recently moved forward to liberalize their insurance sectors on the basis of their own self-interest. These countries are to be commended for their vision. In other cases, such as Pakistan, countries have decided to postpone market liberalization in order to trade it for increased access in textiles or agriculture if and when the Uruguay Round comes to a successful end.

Within the GNS, much work remains to be done and there are still several unresolved issues. The binding of sub-national entities, treatment of state-controlled companies, crosssector retaliation, the scope of liberalization commitments, and the effective size of the initial signatory group - all are issues which have yet to be resolved.

The overall outlook can best be described as mixed. With regard to services alone, one can be optimistic. The framework is generally in good shape even though considerable work remains to be done. Tremendous progress has been made over the last 6 months or so with regard to the financial services annex. The prospect is there for an agreement which goes beyond codification of the status quo and has long-term commercial value. In terms of the broader Uruguay Round negotiations, however, one can only remain pessimistic. One of the key questions which we may have to face in the coming months is whether and how it might be possible to detach the GNS negotiations from other parts of the Round and especially from the deadlock on agriculture.

\section{What now needs to be done}

Let me conclude by offering some unsolicited but hopefully constructive advice to all those who are directly and indirectly involved in the fate of the Uruguay Round:

- We need quickly to broaden the number of demandeurs. The U.S. has been active from the start but now others who can only benefit from an overall agreement must come forward and place a higher priority on the GNS negotiations.

- Technical support for the trade negotiation process needs to be increased. Imagine that today there is really only one EC staff person responsible for monitoring and coordinating the insurance-related trade activities for all Community member states.

- We need to create a proper multilateral forum - as opposed to the bilateral processes used to date - within which the mutual exchange of concessions and an overall balancing of benefits among nations can occur.

- Much more pressure is currently needed on respective governments from non-U.S. financial services firms. Within the U.S., the coalition in support of the multilateral trade negotiations has been broadened considerably and, outside the U.S., the financial services interests should take a more active stance.

- Action by the private sector needs to be taken at all levels: at the level of industry associations in insurance and other services sectors, on the part of industry advisory groups dealing with their respective national governments, and by companies individually.

The prospect of a meaningful multilateral trade in services agreement is within sight. We must act now if we are eventually to realize its potential commercial benefits. 